\title{
Needs Analysis and Effectiveness of Learning Outcomes with Competence-Based Learning Application
}

\author{
Zulkifli Matotondang ${ }^{1}$, Syafiatun Siregar ${ }^{2}$, Sempurna Perangin-angin ${ }^{3}$, Ahmad Andi \\ Solahuddin ${ }^{4}$, Kinanti Wijaya ${ }^{5}$ \\ \{zulkiflimato@gmail.com\}
}

Fakultas Teknik, Universitas Negeri Medan, Jl. Willem Iskandar Pasar V Medan Estate, Medan, Indonesia ${ }^{1,2,3,4,5}$

\begin{abstract}
Construction work is an activity carried out by building construction workers related to infrastructure development or civil works. Construction workers are people who are directly involved in project implementation and play an important role in achieving project objectives. Generally, construction workers do not have basic skills, let alone competence in entering the building construction work market. The purpose of this study is to produce an analysis of learning material needs and produce an analysis of the effectiveness of competency-based learning. The results of the study were 1) The results of the instrument validity test on learning needs were declared valid 2) Materials for the Stone Concrete Settlement Work stated that concrete stone finishing work was needed to build construction workers, 3) The results of the analysis of the task evaluation, psychomotor and affective on the CBL model stated that all three aspects are considered very effective to improve the competence/knowledge of building construction workers.
\end{abstract}

Keywords: Needs Analysis, Effectiveness, Competence-Based Learning

\section{Introduction}

The development of the construction management sector needs to be balanced with the presence of workers or workers with good quality human resources. Aspects of human resources are construction workers in the field, namely construction workers who are directly involved in project implementation and play an important role in achieving project objectives. Project workers in the field, in this case, building construction workers are identical with hardsector jobs, where the majority are male workers. In entering work as a building construction worker, it is not expected to have a high education. Likewise, in entering the world of construction work, construction workers are very easy to enter this work field. Considering that construction work has never run out, construction workers will be very easy to find jobs in this field. Generally, the job as a construction worker is with a high school education background.

The formal job market requires high competitiveness for formal job seekers. The formal job market requires a formal educational background in entering it. In other words, if you want to enter the formal job market, you must have educational legalities such as a diploma or other expertise certificate. This will have an impact on low-educated urban residents who are unable to enter the formal labor market. Medan City statistical data in August 2017 states that the 
number of people with lower levels of education than high school reached $32.23 \%$ of the total population of Medan City which reached 2.5 million. Whereas of the total population, the productive workforce working in the informal sector reached $57.50 \%$. The results of interviews with several contractors in the city of Medan stated that generally, construction workers with the highest education were graduating from high school. Generally, construction workers do not have basic skills, let alone competence in entering them. In addition, construction workers also do not need capital (financial) while the world job market of building construction is quite broad and never stops both large and small scale.

Building construction competence is divided into several skills such as concrete stone engineering, steel engineering, wood, building drawings, furniture and so on. Concrete Stone Engineering expertise competencies have basic competencies such as foundation installation, wall, stamping, finishing and others. The results of the interview with the contractor stated that one of the promising basic competencies in building construction was finishing work. Included in finishing work are ceramic installation, moulding techniques, and wallpaper installation. This will be the basis of this research to provide basic competencies for building construction workers. If this basic competence is given to building construction workers, it can have an impact on increasing competitiveness, competitiveness and ultimately can improve the welfare of building construction workers.

To overcome the facts above, it is necessary to conduct research on how to improve competence for building construction workers. Competence is human measurable ability needed to improve effective work performance. Model and competency analysis is to identify various people management systems such as workforce planning, selection, employee development, performance management and welfare improvement (Sultana, A, 2014). Companies that adopt competency-based labor practices find solutions to effective management problems and monitor their workforce in the new world of work. Therefore it is necessary to research the development of competency-based learning models whose results are to develop a competent workforce, competitive in the world of work can improve the level of welfare of workers.

To purpose of this study are to producing needs analysis Competency-based learning and to generate an analysis of the effectiveness of competency-based learning outcomes for construction workers.

\section{Literature Review}

\subsection{Competency-based Learning}

Competency-Based Learning (CBL) is learning that is carried out with an orientation towards achieving students' competencies. So that the final estuary of learning outcomes is an increase in the competence of learners that can be measured in the pattern of attitudes, knowledge, and skills (Purnomo: http://kidispur.blogspot.com). Furthermore in the aspect of learning, the Ministry of National Education (2002) states that competency-based learning has the following five characteristics: (1) Emphasizes the achievement of the competencies of students both individually and classical; (2) Oriented on learning outcomes and diversity; (3) Submission in learning using various approaches and methods; (4) Learning resources are not only lecturers but also other learning resources that fulfill educational elements; (5) 
Assessment emphasizes learning processes and outcomes in mastery efforts or achievement of competence.

In line with this, according to Gonczi (1998: 38), important characteristics are found in competency-based education models, including (1) a list of competencies that are documented accompanied by specific standards and conditions for each competency; (2) at any time students can be assessed for achievement of their competence; (3) learning takes place in a module format that is related to each competency; (4) assessment based on certain standards in competency statements; (5) most of the skills-based assessments are demonstrated in real terms; (6) students can obtain exemptions from the learning section and proceed to the next work unit based on the competencies that have been achieved; (7) student learning outcomes are recorded and reported in competency statements.

\subsection{The Model of Competency-based Learning}

Competency-based learning model building construction workers are designed with the following characteristics: (1) The learning approach used is adult learning; (2) Planning learning includes the preparation and formulation of objectives, learning methods and techniques, learning materials and materials, resource persons, learning media and evaluation of learning; (3) Learning methods that are considered appropriate to the needs of adult students who have worked are participatory learning because this learning actively engages students in learning activities ranging from planning, implementation to evaluation. Besides that participatory learning has principles derived from the needs of students, goal oriented, learner-centered and based on learning experiences; (4) Learning materials related to the needs, daily life and experience of students, namely as construction workers. The material presented in the form of basic building with earthquake-resistant building construction; (5) The media used is media that has conformity with the objectives of teaching, can stimulate thinking and generate the same perception, interesting and clear, easy to obtain, easy to use and adapted to the level of thinking ability of students. The types of media used include images, color photos, videos, and original forms; (5) The resource person or facilitator has a background that is appropriate to the activities that will be given, experts or have experience and know the learning methodology, able to use the media, communicative and able to provide motivation; (5) Evaluation is carried out before and after learning which aims to assess the achievement of goals.

\section{Methods}

Construction work is an activity related to efforts to develop infrastructure or civic buildings, which have a series of activities and fulfill the requirements and through a certain scope of work carried out by a group of people. Construction work is identical to work in construction projects where construction work only takes place temporarily and in a limited period. Construction projects allocate certain resources to carry out tasks whose targets are clearly outlined.

\section{Results And Discussion}




\subsection{Need Analysis}

The analysis carried out was to analyze the need for the development of learning models, analyze the feasibility/needs and prerequisites in the development of new learning models. The problem that occurs is because the existing learning model is not relevant to the needs, learning environment (facilities and infrastructure), technology, characteristics of students, and so on. The implementation of learning programs is carried out because of problems such as lack of skills and knowledge/competencies that lead to the low performance of individuals in the organization or company. Improvement of the quality of knowledge and skills is carried out due to the low competency of the participants in this case construction workers in entering the building construction work. Therefore, it is necessary to do a needs analysis, namely to determine the abilities or knowledge/competencies that need to be learned by participants to improve performance or knowledge/skills that have implications for increasing competence. Analysis of learning needs is carried out through questionnaires to stakeholders (users) in this case educators, practitioners, and instructors. The dissemination of this questionnaire aims to obtain data on the need for learning to be taken during the research process. The results of the distribution of questionnaires were processed and analyzed to determine the competencies/knowledge needed in concrete stone finishing work. There are two instruments examined, namely the needs analysis validation instrument and the learning needs analysis. Researchers provide questionnaires, each of which consists of 47 statement items and questions.

Analysis of the instrument of the validity of learning needs using Aiken's formula in determining Valid or invalid items of the instrument given. Assessment is done using a Likert scale where score 5 (Very Valid) for the highest score and score 1 (Very Invalid) for the lowest value. The results of the analysis of the validity instrument are carried out with the aim to obtain the validity of the analysis of learning needs designed. The result is the validity of the learning needs instrument can be seen in Table 1. Below

Table 1: Instrument Validity Analysis Tests Learning Needs

\begin{tabular}{|c|c|c|c|c|}
\hline No & Rated aspect & $\begin{array}{c}\text { Number of } \\
\text { items }\end{array}$ & V Aiken's & Information \\
\hline 1 & Workplace safety & 9 & 0,906 & Valid \\
\hline 2 & $\begin{array}{l}\text { Inspection of } \\
\text { building materials }\end{array}$ & 12 & 0,906 & Valid \\
\hline 3 & $\begin{array}{l}\text { Concrete Stone } \\
\text { Work Tools }\end{array}$ & 13 & 0,888 & Valid \\
\hline 4 & Plastering Work & 5 & 0,877 & Valid \\
\hline 5 & $\begin{array}{l}\text { Tile and Ceramic } \\
\text { Installation }\end{array}$ & 3 & 0,890 & Valid \\
\hline \multirow[t]{2}{*}{6} & $\begin{array}{l}\text { Moulding } \\
\text { Techniques }\end{array}$ & 5 & 0,900 & Valid \\
\hline & Summary & 47 & & Valid \\
\hline
\end{tabular}

The results of the instrument validity test on learning needs are Valid with an average Aiken's $\mathrm{V}$ value of 0.870 . V Aiken's value obtained $0.870>0.600$ is stated in the valid category. The highest result of validity is on the health aspects of workplace safety and inspection aspects of building materials that is 0.906 , this is because every building construction work must pay 
attention to the importance of occupational health and safety. Likewise, with the need to inspect building materials starting a building construction work. Overall from table 1, it can be valid because all the validity values obtained are greater than 0.600 .

Analysis of competency-based learning needs for building construction workers is concrete stone finishing work. This questionnaire uses a rating scale with a scale of $1-5$. Where the value of 5 for material that is badly needed, a value of 4 is needed, the value of 3 is doubtful, a value of 2 for less material is needed and a value of 1 for material that is not needed. This questionnaire was validated by 5 (five) stakeholders consisting of educators, practitioners, and instructors.

From the 47 questions distributed to retrieve data on concrete stone work needs, there were 6 aspects assessed: 1) Workplace safety, 2) Building Materials Inspection, 3) Concrete Stone Works, 4) Plastering Work, 5) Installation of Tiles and Ceramics and 6) Moulding Techniques. Each criterion that is judged to have a different item is adjusted to the needs for its analysis. Based on the questionnaire data analysis, the need for concrete stone finishing work learning model can be seen in Table 2 below:

Table 2: Results of the Questionnaire Analysis of the Validity of Concrete Stone Finishing Works

\begin{tabular}{|c|c|c|c|c|}
\hline No & Rated aspect & Avg & $\%$ & Information \\
\hline 1 & $\begin{array}{l}\text { Healthy safety } \\
\text { work }\end{array}$ & 4,622 & 92,44 & Very Needed \\
\hline 2 & $\begin{array}{c}\text { Inspection of } \\
\text { building materials }\end{array}$ & 4,550 & 91,00 & Very Needed \\
\hline 3 & $\begin{array}{l}\text { Concrete Stone } \\
\text { Work Tools }\end{array}$ & 4,508 & 90,15 & Very Needed \\
\hline 4 & Plastering Work & 4,560 & 91,20 & Very Needed \\
\hline 5 & $\begin{array}{l}\text { Tile and Ceramic } \\
\text { Installation }\end{array}$ & 4,600 & 92,00 & Very Needed \\
\hline \multirow[t]{2}{*}{6} & $\begin{array}{l}\text { Molding } \\
\text { Techniques }\end{array}$ & 4,480 & 89,60 & Needed \\
\hline & Average & 4,553 & 91,07 & Very Needed \\
\hline
\end{tabular}

Based on the results of the needs analysis, it can be concluded that the Concrete Stone Finishing Work material for planning education and training programs is needed. This is seen from the average percentage of 91.07 which is categorized as 'very needed'. From the results of the above analysis strengthen researchers to conduct research by developing a CBL model of building construction workers.

\subsection{Implementation}

The implementation phase is carried out on education and training participants in this case building construction workers. The implementation of CBL was carried out at the Civil 
Engineering Workshop of the Faculty of Engineering Unimed by implementing the developed learning model. Furthermore, participants will implement the knowledge and skills gained from education to be applied in the building construction work. The task assessment is carried out by observing participants in doing Concrete Stone Finishing work.

\subsection{Effectiveness of Learning Outcomes}

Building construction workers as education and training participants were 27 people, who were assessed based on observations. Assessment is carried out by instructors, and supervisors during the activity. Based on the processing of data from the assessment of the tasks performed, the results of statistical analysis are as follows. Task assessment includes 1) Having an action plan, 2) Use of materials, 3) Use of tools, 4) Work steps, 5) Cooperation and interaction, 6) Understanding of work, 7) Presentation, 8) Appropriateness of work size, 9) Ability to analyse work, and 10) Make new work ideas. The results of the task assessment statistics can be seen in Figure1.

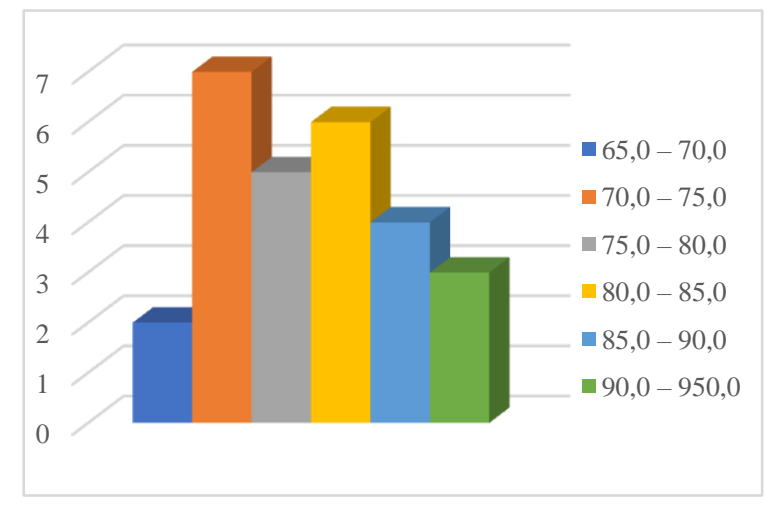

Figure 1: Histogram assessment CBL'smodel tasks

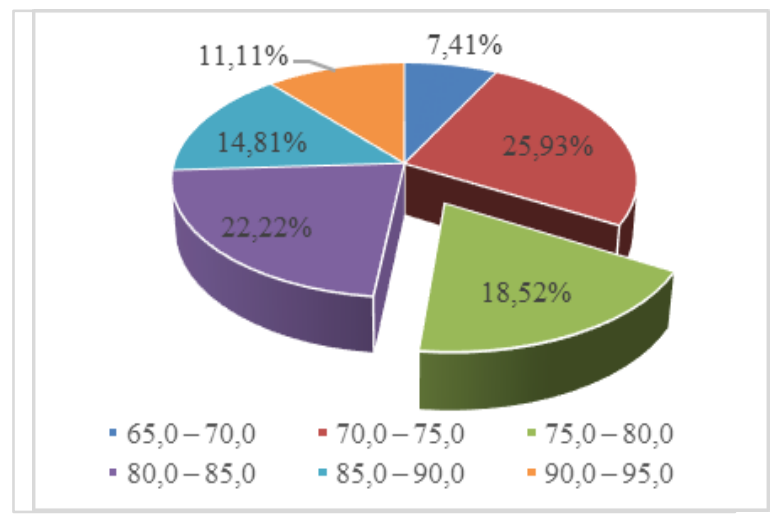

Figure 2: Percentage of Task Assessment CBL's Model

Figure 1 and Figure 2 show the results of the statistical evaluation of CBL participants in evaluating the task assessment of the 10 observed criteria. The results showed that there were 
still 2 participants $(7.41 \%)$ who had not reached 70 . While 25 participants $(93.59 \%)$ had scored above 70 . The highest assessment results were within the $70.0-75$ score range, 0 is $25.93 \%$ ( 7 people). Overall the ability of participants can be said to be good because it has reached the graduation rate of $93.59 \%>80 \%$ (graduation percentage of a class).

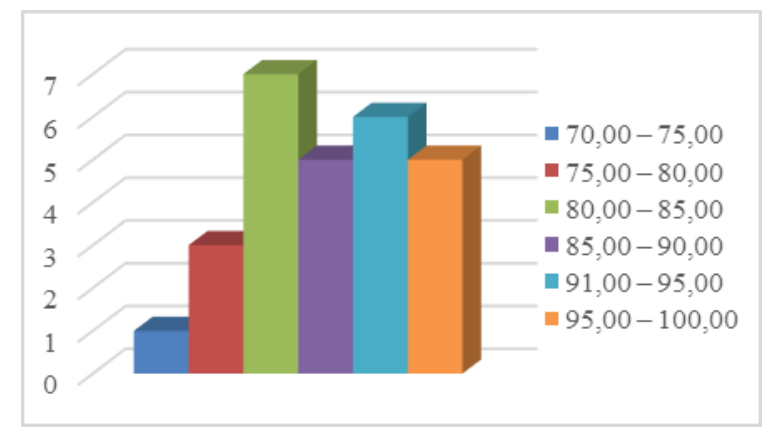

Figure 3: Histogram of psychomotor assessment CBL model

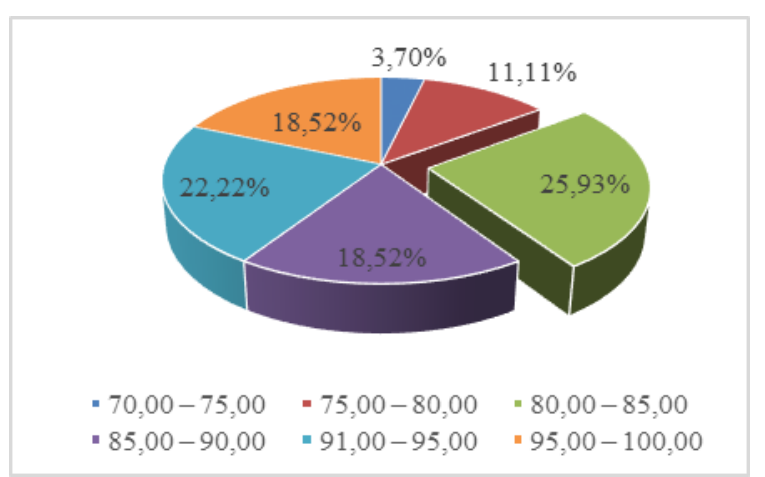

Figure 4: Percentage of Psychomotor Assessment CBL's Model

Figure 3 and Figure 4 show the results of evaluating the statistics of CBL participants in evaluating psychomotor assessment of the 14 observed criteria. Psychomotor assessment criteria consist of Preparation Aspect 4 criteria, process aspects 5 criteria and product aspects 5 criteria. Each criterion is followed by a list of rubrics to facilitate the observation and assessment carried out. The results show that all participants can pass the 70 marks (minimum psychomotor rating). There is only 1 person $(3.7 \%)$ who has a value of $<75.0$. The highest assessment result is in the limit of values of 80.0 - 85.0 of $25.93 \%$ (7 people). Overall the psychomotor ability of participants can be said to be good because it can achieve psychomotor abilities with a $100 \%$ graduation rate.

Affective assessment rubric for participants consists of assessment criteria for attitudes, interests, self-concept, values and morals. Each assessment criterion has 2 statements to mutually reinforce each of the affective assessment criteria. Each assessment criterion is carried out by observing participants in conducting CBL model activities. Each task assessment criteria is assessed with 4 answer choices. The highest score is 4 (four) in the Very Good category, the score is 3 (three) for the good category, the score is 2 (two) for the Poor 
category and the lowest is 1 (one) for the Poor category. This value is then converted to get the value from $0-100$.

Participants in education and training are not only assessed by cognitive and psychomotor aspects, but also by their affective aspects. Assessment is carried out based on observations by the instructor and mentor during the activation process. Based on the processing of assessment data, the results obtained from the statistical analysis are as follows.

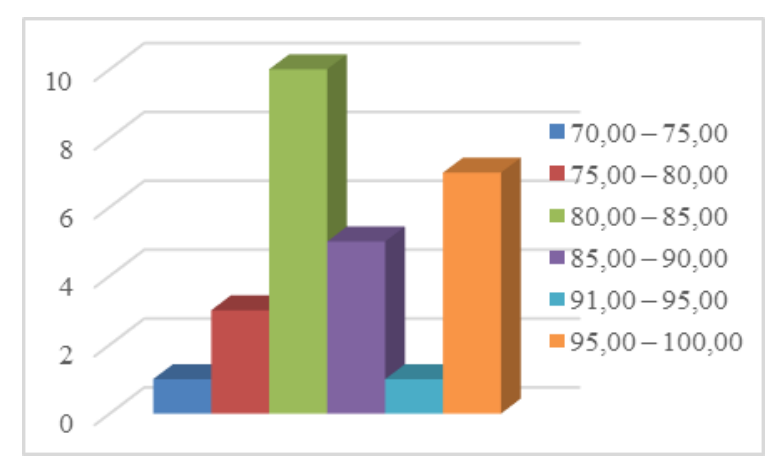

Figure 5: Histogram of the affective assessment CBL's model

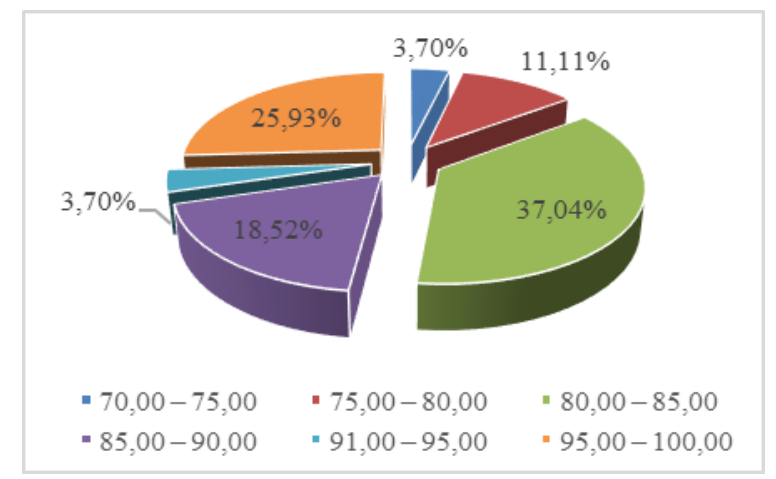

Figure 6: Percentage of affective assessment CBL's model

Figure 5 and Figure 6 show the results of the statistical evaluation of participants in the CBL model in evaluating the affective assessment of the 14 observed criteria. The results show that all participants can pass the 70 marks (the minimum limit for affective assessment). There is only one person (3.7\%) who has a value <75.0. The highest assessment result is in the value limit of $80.0-85.0$ of $37.04 \%$ (10 people). Overall the affective ability of participants can be said to be good because it can achieve the value of affective abilities with a $100 \%$ graduation rate.

\section{Conclussion}

The results of the exposure that have been presented have the following conclusions

- The stage of needs analysis is carried out by analyzing the need for CBL stating that the competence of concrete stone finishing work is very needed. 
- The results of the instrument validity test against learning needs are stated to be valid with the average Aiken's V value of 0.870 .

- Based on the results of the needs analysis can be concluded material Concrete Stone Finishing Work with an average rating scale of 91.07. This value indicates that concrete stone finishing work is needed for building construction workers.

- The results of the task assessment analysis carried out with 10 aspects that were considered to show high results with a passing grade of $93.59 \%$

- The results of psychomotor analysis carried out with 14 aspects that are considered to show high results with a passing grade of $100 \%$

- The results of the affective analysis carried out with 12 aspects that are considered to show high results with a passing grade of $100 \%$

Acknowledgments. This research was conducted at the Unimed Engineering faculty workshop. Therefore, the researcher would like to thank the Dean who has given permission to use the Pendidikan Teknik Bangunan's workshop. To all staff and laboratory assistants who have helped during this research. Thank you very much. May Allah blessing us. 


\section{References}

[1] Alisjahbana.: Marginalisasi Sektor Informal Perkotaan. ITS Press., Surabaya.(2006)

[2] Amalia, L., Suwanto.: Peningkatan kompetensi siswa melalui efektivitas Competency Based Training, Jurnal Pendidikan Manajemen Perkantoran, Volume 1, nomor 1, Agustus 2016, hal 31 - 3, http://ejournal. upi.edu/index.php/jpmanper(2016)

[3] Borg, W. R. \& Gall, M.D.: Educational research: An introduction (4th ed.), NY: Longman (1983)

[4] Fink, K. F., Rokkjaer, O., \&Schrey, K.: Work Based Learning And Facilitated work Based Learning. Aalborg: TREE (Teaching and Research in Engineering in Europe).(2007)

[5] Henri CB.: Technical Education in Namibia: Past Trends, Present Circumstances and Future Prospect, Dissetation, Faculty of Humanities Departemen of Curriculum Studies and Departemen of Comparative Education and Education Management, University of The Free State (2006)

[6] Kent, D. Mushi, p.: The Education and Training of Artisans for the Informal Sector in Tanzania' ISBN: 0902500740 (1996)

[7] Lauglo.J. dan Maclean. R.: Vocationalisastion of Secondary Education Revisited, Springer, Dardrecht, The Netherlands (2005)

[8] Nanang D., H.: Miskonsepsi Tukang Bangunan Dalam Teknik Membangun Konstruksi Tahan gempa, jurnal Teras, hal 59 - 68(2010), Volume X/I/Juli 2010, Universitas Malikul Saleh

[9] Ma'aji, SA dan Hassan, A.M.: Assesing the unemployment Initiative Programme in Collaboration With TVET Institutions in Nigeria, Proceeding of the 2nd UPI International Conference on TVET, Bandung, hal 94-104 (2012)

[10] Malloch M., et all.: The Sage Handbook Of Workplace Learning, Sage, London (2011)

[11] Mcgrath, S. King, k. Et al.: Education and Training for the Informal Sector Vol. I ISBN: 0 902500597 vol.2 (1995) ISBN: 0902500600

[12] Morley, R.: Workplace Learning Guide 2010: Learning for Life in the 21st (2010)

[13] Raimo NN.: The Integration Of Identified Employability Skills Into The Namibian Vocational Education And Training Curriculum, Dissertation, Departemen of Curriculum Studies Faculty of Education Stellenbosch University (2010)

[14] Simon McGrath and Kenneth King.: Education And Training For The Informal SectorEducation Research Paper No. 11, 1994, 332 p with Fiona Leach and Roy Carr-Hill(1994)

[15] Siswanto, B. T.: Pendidikan Vokasi, Work-Based Learning, dan Penyelenggaraan Program Praktik Pengalaman Lapangan. Workshop Penyusunan Buku Panduan Penulisan Laporan KP, TA, Skripsi Fakultas Teknik Universitas Muhammadiyah Magelang, (hal. 1-18). Magelang. (2013)

[16] Siswanto, B. T.: Pengembangan Program Penyelenggaraan Work-Based Learning Pada Pendidikan Vokasi Diploma III Otomotif, Seminar International Aptekindo, ISSN 1907-2066 (2013)

[17] Sudiyatno.:Pengembangan Model Penilaian Komprehensif Unjuk Kerja Siswa Pada Pembelajaran Berbasis Standar Kompetensi DI SMK Teknologi Industri, Disertas, Universitas Negeri Yokyakarta (2010)

[18] Sultana., A.: A Study on Developing Competency of Workforce Planning, International Journal Of Innovative Research And Development, www.ijird.com, pp 164-170 November, 2014, Vol 3 Issue 12 (2014)

[19] Thamrin, M. H.: Implementasi Program Pendidik Teknologi Dasar Di Sekolah Menengah Pertama Dikaitkan Dengan Vokasionalisasi Pendidikan, Jurnal Di SainTek Vol. 01, No. 01 Desember (2007)

[20] Work-based learning guide 2002. Diakses pada tanggal 2 Pebruari 2016, dari: http://www.iowaworkforce. org/files/wlg02.pdf 